\title{
Polycystic Ovarian Syndrome: management with Ayurvedic prospective
}

\section{Monika H. Kathoke*1, Bhawana Bhalmey ${ }^{2}$, K. K. Daulatkar ${ }^{3}$}

1. MD Scholar,

2. Professor, Email: mailme_bhaman@ @rediffmail.com

3. Professor \& HOD, Email: daulatkar@gmail.com

Dept. Samhita \& Siddhant, Bhausaheb Mulak Ayurved Mahavidyalaya,

Nandanwan Nagpur, Maharashtra, India

*Corresponding author: monikaluharia@gmail.com

\begin{abstract}
:
Polycystic Ovarian Syndrome is one of the most serious medical conditions associated with a pregnant women, particularly young women and It is linked to miscarriage, erratic menstrual cycle and a disturbed body mass index.
\end{abstract}

Disease incidence increases mostly day by day because of undisciplined living style, diet, depression etc. This leads to both physical and mental disorder of the patient and, if not cared for and treated, can also lead to miscarriage or frequent abortion.

PCOD is one of those condition which typically affects second or third decade of life in females. It is important to know thoroughly about this disease as modern science has no root cause cure to treat it even the treatment of modern science implicated leads to severe side effects and dependence of the drugs.

PCOD is diagnosed in Ayurveda according to its presentation in so many ways like hetu, lakshana, dosha-dushya, samprapti, associated features of PCOS are closely resembling with vandhya yonivyapada, artava-vahastrotas- viddha lakshana, nastartava and ksheena- artava decribed by acharya sushruta and pushpaghni jatharini and vikruta jatharini mentioned by acharya Kashyap.

\section{Introduction:}

Polycystic Ovarian Syndrome (PCOS) is a condition linked to the reproductive age endocrine system of women. Women of PCOS with fluid deposited in it with enlarged ovaries. Another clinical characteristic of PCOS is irregular menstrual cycle, hair growth, obesity, acne and infertility. The disorder is also concerned with dyspareunia, lower abdominal pain and abdominal expansion. Pathological disease involves imbalances of the hormonal system which affect follicular growth during an ovarian cycle, and such follicles remain unbalanced with the ovary. The disease associated with follicle stimulating 
hormone $(\mathrm{FSH})$ and lutenizing hormone (LH) secreted from the pituitary gland of anterior disease. (1) The use of hormonal therapy and surgical procedure seems to be part of modern treatment approaches.

The ayurveda described disease under the heading Raktagulma. Vata vitiated due to Nidansevan then aggravated \& enters into Garbhashaya leads obstruction in Artavvaha Srotas. The vitiated Vata and Dushti Rakta accumulated gradually and develop as Pinda around the wall of uterus; Raktagulma, Pitta, Kapha, Medas, Ambhuvahasrotas \& Artava Dhatu are also associated with PCOS. Ayurveda described that aggravation of etiological factors leads vitiation of Vata, Pitta \& Kapha Dosha, these vitiated Dosha along with Dushti Rakta may trigger PCOS.

\section{Nidana (causative factors):}

In PCOS functional aetiology condition is still unclear and as such is diagnosed as an omission of other androgena and ovulatory disorders of well specified aetiology. We can connect PCOS to Nastartava and Vandhya Yonivyapada. As our classics do not explain any particular aetiology, general causative factors may therefore be taken as etiological factors for Yonivyapada:

\section{Mithyachara}

Mithyachara (faulty dietary habits) and Mithyavihara (faulty life styles) are also included. Under Mithyachara pizza, steak, bread, cold beverages, salty, fatty and frozen food in poor diets are commonly grouped.

It was found that, fast dietary changes is estimated in $5 \%$ to $10 \%$ in the general population due to westernised diets and lifestyle prevalence in reproductive age of women. A survey study conducted on 100 subjects concluded aggravating factors which includes Aharaja Nidana including Aashana, Vishamashana, Ati Madhura Ahara Sevana, Ati Katu and Vidahi Ahara Sevana and Viharaja Nidana includes Avayama, Divaswapana, Ratrijagrana, Mutra vegdharana and Atichinta, so they can be regarded as Mithyachara in PCOS (2).

\section{Pradushtartava}

For ovarian hormones, the term Artava should be used. Due to the cyclic endometrial dissipation under influence of different HPO axis hormones the menstrual flux. In PCOS ovarian compartment is the biggest contributor of androgens. CYP 17 dysregulation may be the primary pathological cause causing PCOS hyperandrogen formation in both the adrenales and the ovaries.

\section{Bijadosha}

The Bijadosha includes chromosomal and genetic abnormality. Excessive exposure to androgens during intrauterine life has a lasting effect on the expression of genes that results in PCOS and then in resistance to insulin. PCOS is an ovarian disease genetically influenced that is defined by the interplay of the condition and the other genes and the environment. The genetic origin is probably polygenic and/or multifactorial, even if low birth weight and foetal exposure to androgens contributes to PCOS phenotype development. Genetic factors are indicative of the high prevalence of PCOS or its characteristics in first-grade relatives. A study showed that the gene-driven linkage of polymorphisms in steroidgenic genes is supposed to regulate the resistance of 
PCOS as a phenotypical heterogeneity (2). Genetic associations are high in genes such as CAPN10, Cytochrome family P450, Insulin gene, AR, FTO and FSHR (2).

Daiva is responsible for unknown or idiopathic reasons. Each cause has its own mechanism of causation, potential and mode of action.

\section{CLINICAL FEATURES:}

Following are the most commonly seen clinical features of PCOS (3):

1. Irregular menses- most prominent feature in which menstrual periods used to be greater than 35 days, less than eight menstrual cycles a year.

2. Ammenorrhea-lack of menstruation for four months or more.

3. Variation in menstrual bleedingProlonged intervals that can be scanty or excessive flow of clots. Bleeding can last to more than 9days.

4. Infertility- due to anovulation, not able to get pregnant.

5. Skin Modification

6. Obesity-Abnormal increase in weight, normally with more weight around the waist.

7. Hair dilution Increased levels of androgen can induce male pattern baldness due to extreme hair loss.

8. Acanthosis nigricans-Patches of skin on the neck, arms, breasts, or thighs.

9. Skin tags- Excess flaps of skin in the armpits or neck area.

10. Pelvic Pain

11. Sleep apnea.

\section{AYURVEDIC PERSPECTIVE OF PCOS}

Ayurveda defines PCOS with the Dosha, Dhatu and Upadhatu fair participation. The signs of this disease are similar to the definitions Anartava-Amenorrhea and Yonivyapad- anatomical and physiologic reproductive disorder, such as Arjaska-oligomenorrhea due to vitiation of vata dosha, Lohitacshayaoligomenorrheas due to vitiation of vatapitta dosha, Vandhya-infertility, and are not related to one disease or syndrome. Abeejata-anovulation, pushpaghnirevati-diosyncratical anovulatory menses, Dusht-Menstrual condition caused by Dosha vitiation Rajodushti and Ashtartava, Dushti Yonivyapad-YoniviVity Shandhi. Menstrual abnormalities may or cannot be associated with anovulation due to genetic conditions. Vishama ahara and vihara (improper diet and work) which reduces the digestion and the metabolism of the digestive extract and creates immature rasa, which vitiates men's blood and increases the amount of meda dhatu and kapha, which cause body channel obstruction and vata prakopa, which causes obesity or amenorrhoea. Vata and Kapha doshas as well as vishama aahar and Vihara contribute to decreased digestive fire (undigested food). This ama production causes inappropriate enzyme reactions which lead to incomplete hormonal imbalance and metabolism. This hormone deficiency induces high hyperinsulinemia and hyperandrogenism, which eventually result in anovulation and amenorrhea / oligomenorrhea. In the words "hormones," Ayurveda does not speak. The vocabulary and words are special to it. Hormones are regarded as tissue fire components. Hormone activity reflects the essence of pitta, the 
transformational force. The interplay of hormones results in all phases of the female reproductive process. The result of pitta replicating the hormones at the different phases of the ovaries and menstrual cycles is the reason behind the alteration of each point. When pitta prevails, hair loss and inflammation, excruciating menses, coagulation, and heart defects are manifested. High cool qualities of Kapha feed the regeneration of the tissue, including the nutritive energy that supports follicle growth during the ovarian cycle, and support the reproductive system. The prevailing Kapha shows elevated weight, subfertility, hirsutism, diabetes and coldness. Vata will reliably influence follicle's movements throughout the ovary period, ovary wall breakdown to releasing the ripened ovum, the fimbriae's movement, and ovum movements near the uterus. The follicle moves via the ovaries. Painful lines and scanty or less menstrual blood and extreme menstrual irregularities are the predominant elements in vata. (4) Appendix (4)

\section{Management}

PCOS control can be aimed at normalisation of the menstrual cycle, ovulation and the elimination of hirsutism, acne to decrease weight and control hyperglycaemia and hyperlipidemia to alleviate cardiovascular danger. Acharya Dalhana said that she has fewer chances of getting Prameha because of daily menses because impurities are continuously being excreted from the women's body (5). Hyperinsulinemia is one of the causes of PCOS and Pramehghna can be used. Weight reduction increases the circulating levels of androgen and glucose but also helps in ovulation and thereby reduces the miscarriage rate for obese women with PCOS. Patients with PCOS rely only on their symptoms in their treatment line. Therefore, administration for PCOS with the following considerations should be prepared.

\section{Nidana Parivarjana}

Avoiding causes that cause disease, Nidana Parivarjana should be followed by women by the Swasthya Rakshana concepts of Dincharya (daily diet), Sadvritta, Acharia-Rasayana, Nidra, Samyaka (6-8 hours' sleep) and Vyayama (physical activity) to deter illness (6-8 hours' night sleep). Study findings showed slight dietary differences, a single, fortified diet results in increased weight loss; low-glycaemic diets have been lowering insulin, fibrinogenic, total density and high lipoprotein, and menstrual disturbances have been enhanced (6).

\section{Exercise}

Several experiments show that routine practise increases menstrual irregularity and resistance to insulin. PCOS shows an increase in body weight index, waist circumference and metabolic metrics such as insulin tolerance, overall cholesterol and profile lipid in physical activity and exercise for 30-45 minutes. This reduces the metabolic syndrome and other PCOS risk factors (7).

\section{Drugs used for PCOS}

Yashtimadhu- Glycyrrhiza glabra L. (Family-Fabaceace) Liquorice effect has already been examined on metabolism of androgen and it has been found that the block of 17-hydroxysteroid dehydrogenase and of 17-20 lipase will 
trigger serum testosterone reduction. Thus, hirsutism and PCOS profit from liquorice (37).

Meshshringi Gymnena sylvestre R.BR. (Family-Asclepiadaceae) Gymnena supplementation studies recorded reduction in absorption of glucose, stimulation of pancreatic beta cell growth and insulin release from beta cells Beta cell supplementation (38).

Shatavari Asparagus racemosus Willd. (Family-Liliaceae) A number of studies show that infertility is advantageous, since it induces folliculogenesis, ovulation, trains the womb for pregnancy and removes errors. Your alcohol extract greatly improves the release of insulin (2)

Methika-Trigonella foenum graceum $\mathbf{L}$. (Family Fabaceace) Studies on Trigonella foenum seed extract showed that ovary volume and cyst size were significantly reduced. The rise in $\mathrm{LH}$ and FSH was also seen.

\section{Kumari Aloe vera L. (Family-Liliaceae)}

- Experimental tests have shown that Aloe Vera reduces testosterone and insulin levels by improved levels of progesterone and estradiol; reduces steroid receptor transcription levels; (41). Aromatase is a family member of the cytochrome $\mathrm{p} 450$ which converts testosterone to estradiol and androstenedione to oestrogen. Many preclinical studies have indicated the involvement of hyperglycaemia and modulation of steroidogenesis in reversed estrus cycles to normal.

Jatamamshi Nardostachys jatamansi DC. (Family Valerianaceae) It is reported to be beneficial in management in PCOS by its antiandrogenic effect (2).
Lodhra- Symplocos racemosa Roxb. (Family-Symplocaceae)- Bark in menorrhagia and other sexual dysfunctions for the females is recommended. Many laboratory trials have shown that testosterone is substantially reduced and oestrogen, progesterone, and cholesterol levels are restored. The normal weight and histology of the ovarian tissue were preserved, and these results were compared to clomiphene citrate (2).

\section{Investigation by modern techniques:}

\section{INVESTIGATION}

1. Ultrasonography:-12 or more follicles in each ovary measuring $2-9 \mathrm{~mm}$ in diameter $+/$ - increase ovarian volume $(>10 \mathrm{ml})$

2. Biochemical evidence of hyperandrogenism : serum total testosterone (>150ng/dl)

3. FSH \&LH levels and its ratio $>1: 3$

4. Insuline resistance:- raised fasting insulin levels >25 microne $\mathrm{IU} / \mathrm{ml} 23$

5. Follicular study

\section{Management}

The basic principles in the management of PCOD according to Ayurveda are as follows -

1) Nidan Parivarjana

2) Ayurvedic Drugs Used

3) Panchakarma Treatment (Shamana/Shodhana)

4) Diet \& Lifestyle Modifications (pathya aaharvihar-dinacharya and rutucharya)

5) Yogasanas/Vyayam.

\section{1) Nidana Parivarjana}


Nidana Parivarjana (avoid the conditions that cause the disease) for which women should observe Swasthya Rakshana rules, such as Dincharya (daily regimen), Rituharya (seasonal scheme), Sadvritta, Achara Rasayana, Hitahara, Samyaka Nidra (sleeping 6-8 hour) and Vyayama (physical activity) for disease prevention. Studies also shown that dietary differences have been subtle, that the monoinsaturated enriched diet lead to greater loss of weight; low glycemic diets reduced tolerance to insulins, fibrinogens, overall and high density of lipoproteins; (6).

\section{2) Ayurvedic Drugs Used}

Yashtimadhu- Glycyrrhiza glabra L. (Family-Fabaceace) Effect of liquorice was investigated on androgen metabolism and it is found that it can reduce serum testosterone might be due to block of 17- Hydroxysteroid dehydrogenase and 17-20 lipase. Thus, hirsutism and PCOS benefit from liquorice.

Meshshringi Gymnena sylvestre R.BR. (Family-Asclepiadaceae) Gymnen's supplementation studies have shown that it decreases glucose uptake, enhances pancreatic beta-cell development, and releases insulin from beta cells (38).

Shatavari Asparagus racemosus Willd. (Family- Liliaceae) Many studies show that infertility is useful as it promotes follicular folliculogenesis, ovulation, prepares the uterus and avoids miscarriages. Its alcohol extract improves insulin release greatly (2)

Methika- Trigonella foenum graceum $\mathbf{L}$. (Family Fabaceace) Studies on seed extract of Trigonella foenum shown significant reduction in ovary volume and size of cyst. It also showed increase in LH and FSH .

Kumari Aloe vera L. (Family- Liliaceae)

- Experimental tests have shown that Aloe Vera reduces testosterone and insulin levels by boosting progesterone and estradiol; reduces steroid receptor transcription levels; increases aromatase expression (41). Aromatase is a part of the p450 cytochrome family that transforms testosterone into estradiol. Many preclinical studies identified the involvement of hyperglycaemia and steroidogenesis in reversing the estrial cyclicity to usual.

Jatamamshi Nardostachys jatamansi DC. (Family Valerianaceae)- It is reported to be beneficial in management in PCOS by its antiandrogenic effect (2).

Lodhra- Symplocos racemosa Roxb. (Family-Symplocaceae)- Its bark is prescribed in menorrhagia and other female reproductive dysfunctions. Many experimental studies proven that it significantly decreases the elevated levels of testosterone and restored the levels of estrogen, progesterone and cholesterol levels. It maintained the normal weight and histology of ovarian tissue and these effects were found to be comparable with clomiphene citrate (2).

\section{3) Ayurvedic Panchakarma}

\section{Shamana chikitsa-}

Rason, satpushpa, and shatavari should be given.

Agni deepan-The management approach to PCOS should concentrate on treating Agnimandya at jatharagni and dhatwagni level and alleviating srotovarodham and ultimately regularizing the apanavata, Eg. Trikatu, Chitrak etc. 
Ama pachan - ama is another important factor causing PCOD. Thus ama pachan gives better result in the treatment. Eg. Aarogyavardhini vati.

Kapha nashan - tikshna and ruksha aushadhi like trikatu for treating obesity in pcos. E.g. guggul kalpa Lekhan - as there is kapha dosha dominance and ama leading to strotorodha, lekhan treatment is to be given. Eg. Kuberakha vati etc.

Vata kapha hara chikitsa- To clear the avarana; for the proper follicular genesis and ovulation with the help of Varunadi Kwath and Dashmool Kwath.

Udvartan - it helps in the management of skin disorders.

2. Shodhan chikitsa- Acharya Sushruta told that in Artava Kshaya Samshodhana should be done followed by use of Aagneya Dravya (45). Dalhana commentates that for purification only Vamana Karma should be used, not Virechana Karma. As Virechana Karma reduces Pitta which results in Artava Kshaya. Vamana Karma expels Saumaya (Kapha) substance results in relative increase of Aagneya constituent of body, consequently increases Artava. Acharya Chakrapani states that use of both Vamana Karma (emesis) and Virechana Karma (purgation) clears upward and downward channels respectively. So, both procedures should be done.

Vamana Karma Vamana thus reduces body metabolism and acts directly on hepatic metabolism that is at the forefront of the formation of hormones. The relationship between oestrogen and obesity is also direct. Therefore, weight loss will boost androgen and glucose flow as well as aid ovulation and thereby increase pregnancy rates among PCOSbased obese women (46).

Basti Anuvasana Basti is the alternative of oligomenorrhea care in Kashyap Anuvasana Basti (47). According to contemporary medicine, any drug administered through the rectal pathway consumes rectum mucosal and enters systemic circulation. As the Gastrointestinal Tract is entered (GIT), Basti activates the entry of the entry nervous system (ENS) as the ENS is like the CNS. These signals are used to activate endogenous opioids, mostly $\beta$ endorphine, which inhibit gonadotropin through hormone release. Basti can activate parasympathic nerve supply and in turn contribute to follicles production and ovary release (48).

Nasya This can activate olfactory nerve and limbotic system that, in essence, activates gonadotropin releasing neurons, regularising GNRH pulsatile secretion, leading to a standard and usual menstrual cycle. This can contribute to the development of gonadotropin releasing neurons.

Udvartana It is stated to decrease the lipids (49).

Yoga - Asana It should be advised to perform Suryanamaskara in a regular way: S a r v a n g a $\mathrm{n}$ an $\mathrm{s}, \mathrm{P}$ a $\mathrm{s} h$ a $\mathrm{t} \mathrm{n}$ a $\mathrm{n}$ a $\mathrm{n} \mathrm{a}$, Ardha matsayendraana, Matsyasana. A 90 patients randomly split into two categories completed clinical trials. One participant practised traditional exercises during other groups Suryanamaskara, Asanas and Pranayama, calming therapies, yoga and lifestyle workshops, and yogic counselling tension control. In terms of lipid enhancing, like insulin tolerance in 
young girls with PCOS, yoga was found to be more effective than traditional (50).

Pranayama-Nadishodhana Pranayama, Kapalbhati and Bhramri Pranayama should also be practiced as they are beneficial in PCOS.

Kapalabhati - The brain-pancreas endocrine system is considered to have beneficial effects and hence mostly hyperinsulinism and dyslipidaemia are pacified. It also enhances muscular blood flow and increases muscle function of the insulin receptor. It also eliminates longterm practise from waist-to-hip.

\section{4) LIFE STYLE MODIFICATIONS OF PCOS}

PCOS can be prevented / treated with the help of aahar, vihar and aushadh;

\section{$A A H A R$}

Pathya- yava, amalaki, priyangu shali shastik chawal. Balanced diet is essential for normal health. Because dietetic abnormality vitiate doshas which cause various gynecological disease may result infertility. It also produce loss of dhatu which influences hormones causes menstrual irregularity. Abnormal diet hamper nourishment of fertilized egg and implantation of zygote.

Apathya-madhur ras Pradhan aahar (potatoes sweets chocolates), Abhishyandi dravya (dahi, udad, kathal, bhindi etc), junk foods, bakery items, cold drinks, etc. should be avoided.

\section{VIHAR}

1. Dincharya and ritucharya should be followed properly.

2. Weight reduction

3. Yogasanas: Anuloma-Viloma, Kapalbhati and Mandukasan
Vyayam

(exercise)

Suryanamaskar, Bhujanasana,

Salabhasana, Budhakonasana,

Dhanurasana, Suptavajrasanas,

Sirsasana, Sarvangasana,

Matsyasana. These are helpful for weight reduction and to decrease blood sugar level as well and enhances tissue sensitivity to insulin $(80 \%$ of the body's insulin mediated glucose uptake occurs in muscles).

4. Vyayama- just half an hour to one hour exercise at least five days in a week either in the form or aerobic exercise, resistant training or a mix of different form of exercises should be sufficient for women suffering from PCOS. This is a target which is not very difficult to achieve, but again the time spent in sedentary lifestyle has to be cut down which is the most difficult part.

5. Prajagaran.

\section{Conclusion:}

PCOS is a one of the major health problem as it impacts the health of the female and has serious adverse effects on the quality of life. New conventional treatments have a high economic impact on societies when preferring the side effects and cost of fertility medications. PCOS did not explain in Samhita vis-àvis, but in relation to the treatment Acharya made a point. Unnamed disease Dosha and Dushya should be understood and treatment accordingly planned. Vandhya Yonivyapada reveals maximum resemblance to PCOS from all Yonivyapada's. In Ayurveda extended Artava meanings, i.e. menstrual blood, ovum, and hormones help amplify and schedule the course of action for PCOS 
symptoms. The present analysis will address the anticipation of illness, which is considerably more effective, safer and will have lower costs for the proper treatment of pest and related comorbidities by preventing causative causes, herbal medicines, Panchakarma treatment and Yoga.

Reference:

1. Kanchanar Guggulwith Conduction Ofpathya/Apathyain Polycystic Ovarian Syndrome

2. An Ayurvedic Approach in Management of Polycystic Ovarian Syndrome

3. The Aetiopathological Study Of Pcos: A Leading Cause Of Female Infertility With Ayurveda Perspective

4. Concept of Polycystic Ovarian Syndrome: Perspectives of
Ayurveda and Modern Science Patel M G1, Prajapati D P2

5. Moran LJ, et al. Dietary composition in the treatment of polycystic ovary syndrome:

6. a systematic review to inform evidence-based g u i d e 1 i n e s J A c a d N u t r D i e t. 2013 Apr;113(4):520-45

7. Shetty D, Chandrasekaran B, Singh AW, Oliverraj J. Exercise in polycystic ovarian syndrome: An evidence - based review. Saudi J Sports Med 2017; 17:1238

8. Goswami, Priyanka Kantivan, Anubha Khale, and Sunita Ogale. "Natural remedies for polycystic ovarian syndrome (PCOS): a review." International journal of pharmaceutical and phytopharmacological research 1.6 (2012): 396-402.

\section{Cite this article:}

Polycystic Ovarian Syndrome: management with Ayurvedic prospective

Monika Kathoke, Bhawana Bhalmey, K. K. Daulatkar

Ayurline: International Journal of Research In Indian Medicine 2021; 5(4):01- 9 